\title{
THE FGC AND AM STEREO: A DEREGULATORY BREACH OF DUTY
}

\author{
JASON B. MEYER $\dagger$
}

The trend toward governmental deregulation of private enterprise, which began in earnest in the 1970's ${ }^{1}$ and has gathered momentum under the Reagan administration, has had a significant effect on the telecommunications industry. The Federal Communications Commission (FGC) has reduced regulation of operation and maintenance logging $^{2}$ and eliminated minimum aural transmission power requirements. ${ }^{3}$ Similarly, a major effort has been made in Gongress to enact a bill deregulating broadcast programming." In 1984 the FGC justified eliminating or relaxing many licensing requirements on the grounds that such "actions further the Commission's goals of creating, to the maximum extent possible, an unregulated, competitive environment for

† A.B. 1980, Princeton University; J.D. Candidate, 1985, University of Pennsylvania. The author wrote this Comment while a student at the University of Pennsylvania Law School.

1 See, e.g., Depository Institutions Deregulation and Monetary Control Act of 1980, Pub. L. No. 96-221, 94 Stat. 132 (codified at scattered sections of Titles 12, 15 , 22 \& 42 of the U.S.C.) (reducing regulatory control of banks); Airline Deregulation Act of 1978, Pub. L. No. 95-504, 92 Stat. 1705 (codified at 49 U.S.C. $\$ \S 1300-02$, $1305-08,1324,1341,1371-79,1382,1384,1386,1389,1461,1482,1486,1490,1504$, 1551-52) (reducing regulatory control of airlines).

2 See Operating and Maintenance Logs for Broadcast and Broadcast Auxiliary Stations, 48 Fed. Reg. 38,473 (1983).

s The Commission abolished minimum aural power requirements that had previously created a situation in which a station's aural range well exceeded its visual range. As the Commission explained, "[We] will eliminate the minimum television aural power requirement on the basis of competitive marketplace dynamics. . . . [I]t is clearly in the best interest of a television station to broadcast at an aural power level that will not perceptibly degrade their [sic] service to the public." Permitting Stations in the TV Broadcast Service to Operate with an Aural Power of Less Than 10\% of the Visual Power, 49 Fed. Reg. 22,089, 22,092 (1984).

- Early in 1983 the Senate passed S. 55, 98th Cong., 1st Sess., 129 Cong. Rrc. 90 (1983), which deregulates many aspects of programming but not of FCC technical control of radio. This bill has not yet passed the House. Three deregulatory bills relating to the FCC, H.R. 2873, 98th Cong., 1st Sess., 129 CoNG. REc. 2599 (1983); H.R. 2382, 98th Cong., 1st Sess., 129 ConG. REC. 1809 (1983); and H.R. 2370, 98th Cong., 1st Sess., 129 Cong. Rec. 1808 (1983), have been held up in the Telecommunications Subcommittee of the House Committee on Commerce and Energy. H.R. 2382, which would free broadcasters from periodic license renewals, has 230 cosponsers. It has been effectively killed, however, due to the opposition to the bill by Subcommittee Chairman (Timothy Wirth, D-Colo.). Broadcast Talks Break Down, 42 CoNg. Q. WeEkLY ReP. 1073 (1984); Early Showdown Developing over Broadcast Deregulation, 42 Cong. Q. WEEKLY REP. 1073 (1984). 
the development of telecommunications and the elimination of unnecessary regulation and policies."'s

The FGG's present enthusiasm for deregulation has greatly influenced its treatment of the recent innovations ${ }^{6}$ in AM stereo. After five years of proceedings in which the FGG attempted to select one of several AM stereo systems as a national technical standard, the FCC decided in 1982 that the marketplace was better suited than a regulatory agency to make this decision. The FCC thus issued a Final Rule ${ }^{7}$ that permitted different AM stereo systems to compete in the market, even though these different systems are incompatible with each other.

Although deregulation occasionally provides for greater efficiency, better allocation of resources, and incentives for technological growth, such benefits do not necessarily accrue. This Comment asserts that the FGC's treatment of AM stereo is a paradigmatic example of deregulation that is not in the public interest. Part I of the Comment examines the factual background of AM stereo and reviews the FCC's AM stereo proceedings and 1982 Final Rule. Part II discusses the FCG's mandate to regulate in the "public convenience, interest or necessity." In Part III this Comment argues that the FCG's decision to permit incompatible AM stereo systems to compete in the market violated its mandate to regulate in the public interest. The FCC's refusal to select one system as the technical standard has delayed mass adoption of this desirable technology and has raised the cost of AM stereo service to consumers. Furthermore, the FGG's market approach makes it likely that the standard for AM stereo will not be determined by the technical superiority of a particular system but rather by promotional expenses or market power of manufacturers. Finally, Part IV of this Comment argues that the decision-making process employed by the FGC in arriving at its Final Rule was inadequate. The FGC improperly relied on an assumption that competition would be beneficial, rather than carefully analyzing whether in the particular context of AM stereo competition would be advantageous.

- Requirements for Licensed Operations in Various Radio Services, 49 Fed. Reg. $20,658,20,658(1984)$.

- The FCC began to consider authorizing AM stereo in 1977. See infra text accompanying note 15. AM stereo has been feasible, however, for over 20 years. RCA first successfully tested AM stereo in the late 1950's. AM Stations, Hurt by FM, Are Going Stereo, N.Y. Times, Oct. 24, 1982, at 6F, col.1 [hereinafter cited as AM Going Stereo].

7 Radio Broadcast Services; AM Stereophonic Broadcasting, 47 Fed. Reg. 13,152 (1982) [hereinafter cited as Final Rule]. The FGC described the action it took in this opinion as a "[f]inal rule." Id. 


\section{The FCG's Treatment of AM Stereo}

\section{A. Factual Background}

When commercial radio began, all broadcasting was in monaural AM. ${ }^{8}$ Eventually, other broadcast technologies such as television, FM, ${ }^{8}$ and FM stereo ${ }^{10}$ became possible. The FCC has authorized FM stereo broadcasting since $1961,{ }^{11}$ but only began to consider authorizing AM stereo broadcasting in the late 1970 's. ${ }^{12}$

In its rulemaking concerning AM stereo, the FCG has considered six different systems, commonly referred to by the names of the companies developing them: Belar, Fisher, Harris, Kahn/Hazeltine, Magnavox, and Motorola. ${ }^{13}$ All of these systems are compatible with existing AM monaural receivers-each system has a stereo transmitter that can be picked up by monaural AM receivers to produce monaural sound. The AM stereo systems, however, are all incompatible with

- AM stands for "amplitude modulation," a broadcasting process by which audio information is coded into minute changes in the amplitude of the sine wave of the electromagnetic radiation that broadcast transmitting systems project. In the United States commercial AM radio refers to those stations that broadcast in the band of frequencies between 535 and 1605 kilocycles-per-second (kilohertz). See AM Going Stereo, supra note 6.

" FM stands for "frequency modulation," a broadcasting process by which audio information is coded into minute changes in the frequency at which a station broadcasts. In the United States commercial FM stations broadcast in the band of frequencies between 88 and 108 megahertz. For a more detailed explanation of the differences between AM and FM, see AM Going Stereo, supra note 6.

10 One naturally hears in stereo, with the left ear hearing mostly sounds from the left, and the right hearing mostly sounds from the right. Each ear thus hears the world a little differently, a capability that allows us to pinpoint spatially the origin of a sound. Broadcasts received in stereo reproduce this effect of left and right separation, which is especially important to create a more realistic presentation of music. The alternative, monaural sound, combines the left and right channels into a single, unseparated channel.

11 See In re Amendment of Part 73 of the Comm'n's Rules and Regulations (Radio Broadcast Services) to Provide for Subscription Television Service: Further Notice of Proposed Rulemaking and Notice of Inquiry, 3 F.C.C. 2d 1, 24-25 (1966).

12 See infra text accompanying note 15.

18 Belar is an AM-FM system; that is, it uses both amplitude modulation and frequency modulation to "code" its signal. Fisher uses a system with "dual-program capability," or DPC. It is not yet completely technically feasible. The Harris system employs "variable compatible phase multiplex," or V-CPM. Kahn/Hazeltine's system uses "independent sidebands"; it is the only one of the proposed AM stereo systems that can be heard using conventional monaural AM radios (but one needs two radios to do it). Magnavox uses an amplitude modulated and phase modulated signal (AM-PM). Motorola's system broadcasts in what it calls "compatible quadrature amplitude modulation," or C-QUAM.

For a more complex explanation of the differences among the competing AM stereo systems, see $A M$ Going Stereo, supra note 6 . For a highly technical explanation of these differences, see Final Rule, supra note 7 , at 13,160 . 
each other. ${ }^{14}$ For instance, a listener using a Harris stereo receiver who wants to listen to a station using a Motorola stereo transmitter will not be able to hear the broadcast in stereo sound; she will only be able to hear that station in monaural.

\section{B. FCC Proceedings Under the Carter Administration}

The FCC formally began to consider AM stereo on June 22, 1977 when it adopted a Notice of Inquiry ${ }^{15}$ in response to two petitions asking for a rule. Through this Inquiry, the Commission sought to discover how much interest there was in stereo AM broadcasting; it also "sought information on what technical performance standards were desirable or necessary to provide a viable stereo service by AM stations."16

The responses to the Notice of Inquiry indicated considerable interest in AM stereo on the part of station licensees, the consumer electronics industry, and manufacturers of broadcast equipment. Five companies submitted proposals for systems. ${ }^{17}$ Based on this response, the FCC issued a Notice of Proposed Rulemaking ${ }^{18}$ in September 1978 with the initial objective of determining which AM stereophonic system would best serve the listening public. The FCC requested comments and submission of further test data by the proponents of the five systems. ${ }^{19}$

In April 1980 the Commission decided that selection of a single system would best further the public interest. Relying on its staff's technical evaluation, the Commission decided that the Magnavox system was superior and ordered its staff to prepare a Report and Order implementing this choice. ${ }^{20}$

Before the Report and Order could be issued, however, the FCC "received many comments from broadcasting licensees objecting to its initial preference of the Magnavox system" as the technical standard. ${ }^{21}$ At least some of these opposing comments were spurred by Magnavox's competitors, who sent letters to 4000 radio stations urging AM operators to protest the Commission's choice. ${ }^{22}$ Given the winner-take-all na-

14 Final Rule, supra note 7 , at 13,158 .

15 AM Stereophonic Broadcasting: Inquiry, 42 Fed. Reg. 34,910 (1977).

${ }^{16}$ Final Rule, supra note 7, at 13,152.

17 Id. (1978).

18 AM Stereophonic Broadcasting: Proposed Rulemaking, 43 Fed. Reg. 48,659

10 See Final Rule, supra note 7 , at 13,152-53.

${ }^{20}$ Id. at 13,153-54.

21 Id. at $13,154$.

22 Broadcasters Protest Selection by FCC of an AM Stereo System by Magnavox, 
ture of the FCG's decision, this resulting controversy was no surprise.

In preparing the Report and Order, the FGG staff attempted more accurately to quantify its evaluative criteria but was unable to do so because of insufficient data and an inability to compare test data on different systems. ${ }^{23}$ The Report and Order were never issued. Instead, on September 11, 1980, the Carter FCG procrastinated, issuing a Memorandum Opinion and Order and Further Notice of Proposed Rulemaking. ${ }^{24}$ In this Further Notice the FCC requested additional technical information on each of the submitted systems. It also solicited comments on whether the marketplace approach might best serve the public interest and on the feasibility of a "multi-system" receiver that could receive signals in stereo from each of the competing systems. ${ }^{25}$

\section{G. FCC Proceedings Under the Reagan Administration}

Ronald Reagan was elected President shortly after the issuance of this Memorandum Opinion. In the early months of his administration, the new President appointed four new members to the seven-member FCG. ${ }^{28}$ In addition to establishing a Republican majority on the Commission, these appointments provided firm support for the Reagan administration's conservative, deregulatory policies. ${ }^{27}$ The important position of chairman went to Mark S. Fowler, an avowed advocate of deregulation. ${ }^{28}$

The deregulators prevailed when the Reagan FCC addressed the issue of AM stereo. In a Final Rule ${ }^{29}$ issued on March 29, 1982, the FCG announced that it had "reconsidered its earlier rejection of allowing a market determination of an AM stereo system or systems" and was "now persuaded that such a reliance on market forces . . . is

Wall St. J., June 27, 1980, at 30, col. 2.

23 See Final Rule, supra note 7, at 13,154.

24 AM Stereophonic Broadcasting, 45 Fed. Reg. 59,350 (1980) [hereinafter cited as Further Notice].

${ }^{25}$ See id. at 59,351, 59,357.

20 See Quello, Rivera Get Reagan Nods, Broadcasting, June 8, 1981, at 35 (discussing nomination of James $\mathrm{H}$. Quello to replace Charles D. Ferris, and Henry M. Rivera to fill the vacancy created by Quello's nomination); Reagan Chooses Dawson for FCC, Broadcasting, Apr. 13, 1981, at 110 (discussing nomination of Mimi Weyforth Dawson to replace Robert E. Lee); Broadcasting, Mar. 16, 1981, at 56 (discussing nomination of Mark S. Fowler as Chairman of the FCC).

${ }^{27}$ See FCC in 1983: Undaunted Deregulatory March, BROADCASTING, Jan. 17, 1983, at 78; Within the Inner Circle: A Review of the FCC Members, Telephony, Jan. 18, 1982, at 58 (describing the regulatory philosophies and goals of each commissioner). 30.

${ }^{28}$ See The Pro-Business Bent of Mark Fowler, Broadcasting, Mar. 23, 1981, at

29 Final Rule, supra note 7. 
the most prudent course to follow." 30 The FCC characterized its decision to rely on the marketplace as a "bold, new step" that "clearly represents a change from tradition."s1

A majority of four Commissioners reasoned that any selection of an AM stereo system by the FCC "would be highly tenuous." The majority doubted their ability to make the optimal choice because (1) nonuniform testing methods made technical data evaluating the competing systems incomparable; (2) the weights assigned various engineering factors were arbitrary; and (3) even if these data and methodological problems were ignored, the results were close. ${ }^{33}$

The majority claimed that allowing the incompatible AM stereo systems to compete in the marketplace had several advantages. A marketplace approach would not only allow consumers to weigh the various design characteristics themselves, but would also provide an incentive for technological improvement and for reduction of production costs. Furthermore, this free market option would encourage price competition, whereas the selection of a single AM stereo system would give a monopolistic advantage to the manufacturer of choice. ${ }^{34}$

The majority addressed one possible disadvantage of the market approach: it might lead to no AM stereo system being adopted at all. Such a "worst case scenario" might occur if the threat of obsolescence deterred broadcasters and manufacturers from initially investing in a particular system. The majority, however, considered the possibility of this type of standoff unlikely. ${ }^{38}$

Two concurring Commissioners stated that "[o]ne thing the marketplace doesn't do very well and something government should be prepared to do ... is to establish technical standards in the interest of nationwide compatibility." ${ }^{\text {se }}$ The Commissioners concurred in the result, however, because they felt that the FGG's credibility had been so damaged by five years of procrastination that there was "serious question whether [the FCG could] fairly and in a reasonable period of time" set a compatible technical standard. ${ }^{37}$ One Commissioner dissented, arguing that it was in the public interest for the Commission to select a single standard. .8 $^{38}$

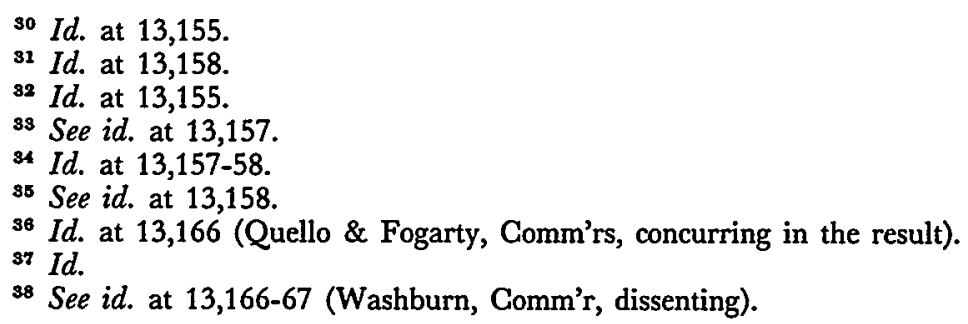


The Final Rule promulgated certain minimum technical standards under which incompatible systems were permitted ${ }^{39}$ and further required that each system obtain FCG "type acceptance" before being introduced into the market. ${ }^{40}$ Four systems obtained type acceptance by November $1982^{41}$ and are now competing in the marketplace. ${ }^{42}$

\section{The FCG's Mandate}

To evaluate the Federal Communications Commission's AM stereo Final Rule, one must first examine the Commission's mandate as it has been articulated in statutes, cases, and administrative proceedings.

\section{A. Statutory Mandate}

Congress created the FCC and delineated its duties and powers in the Communications Act of $1934 .{ }^{43}$ The Act requires the FCC to regulate the broadcasting industry so as to further the "public convenience, interest, and necessity." 44 Furthermore, the Act provides that the FCG

s9 See id. at $13,152,13,158,13,164-66$.

10 See id. at 13,164. Type acceptance is part of the FCG's authorization procedure for ensuring that equipment adheres to certain technical standards. Such standards for radio frequency equipment and components are necessary for the Commission "to carry out its responsibilities under the Communications Act and the various treaties and international regulations, and in order to promote efficient use of the radio spectrum." 47 C.F.R. § 2.901 (1983). See also 47 C.F.R. \$§ 2.981-2.1005 (1983) (detailing type acceptance procedures).

61 Kahn was the first to obtain type acceptance, receiving it on July 23, 1982. AM Stereo Goes on the Air, Broadcasting, Aug. 2, 1982, at 23. The Harris, Magnavox, and Motorola systems had also been accepted by November 1982. TeLEvision DigesT, Nov. 15, 1982, at 10. Belar's initial decision, based primarily on financial considerations, was to manufacture monitors under license for Magnavox rather than engage in the ensuing marketplace struggle. FCC Gives Up on AM Stereo Choice, Will Leave it to Marketplace, Broadcasting, Mar. 8, 1982, at 36, 37. The Fisher system is not yet technically feasible. See supra, note 13.

12 In August 1983 the FCC, finding that the equipment being marketed by the Harris Corporation differed from the system it had submitted for type acceptance, ordered Harris to withdraw its system from the market and notify the stations using it to revert to monophonic broadcasting. FCC Pulls Plug on Harris AM Stereo, BRoADCASTING, Aug. 29, 1983, at 35. Consequently, the Harris Corporation was at a severe competitive disadvantage until September of 1983 when the FGC determined that Harris equipment could once again be used for broadcasting. Wall St. J., Sept. 26, 1983, at 12, col. 3.

ts Communications Act of 1934, ch. 652, 48 Stat. 1064 (1934) (codified at 47 U.S.C. $\$ \S 151-609$ (1976)). The 1934 Act was in large part derived from the Federal Radio Act of 1927 , ch. 169, 44 Stat. 1162 (1927) (repealed by $\$$ 602(a) of the Communications Act of 1934). See FCC v. Pottsville Broadcasting Co., 309 U.S. 134, 137 (1940). The Federal Radio Act created the Federal Radio Commission, the precursor of the FCC.

1447 U.S.C. $\S 303$ (1976). 
has a duty to regulate certain technical aspects of broadcasting. The FCC

shall ... (c) [a]ssign bands of frequencies to the various classes of stations, . . . ; (e) [r]egulate the kind of apparatus to be used with respect to its external effects and the purity and sharpness of the emissions from each station and from the apparatus therein; (f) [m]ake such regulations . . . as it may deem necessary to prevent interference between stations ... . ; (g) [s]tudy new uses for radio, provide for experimental uses of frequencies, and generally encourage the larger and more effective use of radio in the public interest . . . .45

The Act also specifies that one reason for the creation of the FCC was to ensure that radio communication service is made available at reasonable charges. ${ }^{46}$

\section{B. Case Law Interpreting the FCC's Mandate}

The Supreme Court has stated that the "public convenience, interest, or necessity" standard is the "touchstone" for the exercise of the Commission's authority. ${ }^{47}$ Furthermore, the Court has held that competition does not necessarily further the public convenience, interest, or necessity. In FCC v. RCA Communications, Inc. ${ }^{48}$ the FCG assumed that promoting competition was a national communications policy and that competition is in the public interest whenever "reasonably feasible." On the basis of this assumption, the FGC approved a company's request to open new radiotelegraphic circuits to Portugal and the Netherlands that would compete with then existing circuits maintained by another company. ${ }^{40}$

The Supreme Court held that the FCC had erred in concluding that there was a national policy in favor of competition: ${ }^{.0}$

The very fact that Congress has seen fit to enter into the comprehensive regulation of communications embodied in the Federal Communications Act of 1934 contradicts the notion that national policy unqualifiedly favors competition in communication. . . . [E]ncouragement of competition as

15 Id. § 303(c), (e)-(g).

4 See id. $\$ 151$.

17 NBC v. United States, 319 U.S. 190, 216 (1943); FCC v. Pottsville Broadcasting Co., 309 U.S. 134, 137-38 (1940).

48346 U.S. 86 (1953).

40 Id. at 87-89.

so See id. at 89-95. 
such has not been considered the single or controlling reliance for safeguarding the public interest. ${ }^{81}$

According to the Court, the FCC could not justify its decision to foster communication in radiotelegraphic circuits to Europe "[m]erely [by] assum[ing] that competition is bound to be of advantage, "52 or by reciting "in an abstract, sterile way" that competition may have beneficial effects. ${ }^{63}$ Rather, the Court stated, the FCC had a duty to analyze independently, in light of "the trends and needs of this industry," whether competition would be in the public interest. By simply relying on an assumption regarding national policy, the FCC had "abdicate[d] ... one of the primary duties imposed on it by Congress."

The Court concluded that the FGC could decide to foster competition in a particular instance only if after conscientious analysis the FCC concluded that competition was desirable. ${ }^{.8}$ The Court held that the FCG need not demonstrate that competition would have tangible benefits and noted that "the possible benefits of competition do not lend themselves to detailed forecast."'s8 The Commission, however, "must at least warrant, . . . that competition would serve some beneficial purpose such as maintaining good service and improving it, ${ }^{3787}$ and there

s1 Id. at 93. Compare id. at 92-93 ("Federal legislation affecting railroads is a familiar but far from unique example of those many areas of economic activity in which serious inroads have been made on an original policy favoring competition. Indeed, as to the [communications] industry . . . , there has been serious qualification of competition as the regulating mechanism.") with FGC v. Sanders Bros. Radio Station, 309 U.S. 470, 474 (1940) ("IT]he Act recognizes that the field of broadcasting is one of free competition. The sections dealing with broadcasting demonstrate that Congress has not, in its regulatory scheme, abandoned the principle of free competition, as it has done in the case of railroads . . . ."). The difference in the Court's pronouncements can be explained by noting that the Court made the latter statement in the course of holding that an existing station cannot resist the granting of a license to a proposed new station on the grounds that competition would cause it economic injury. Sanders Bros., 309 U.S. at 474-76. In contrast, the Court made the former statement in the course of holding that the FCC could not rely on a national policy of competition to authorize competing radiotelegraphic circuits whenever "reasonably feasible." FCC v. RCA Communications, Inc., 346 U.S. 86 (1953).

${ }^{2}$ RCA Communications, 346 U.S. at 97.

ss Id. at 94. The Commission had simply stated,

Competition can generally be expected to provide a powerful incentive for the rendition of better service at lower cost. Those seeking the patronage of customers are spurred on to install the latest developments in the art in order to improve their services or products, and in order to enable them to reduce expenses and thereby lower their rates or prices. The benefits to be derived from competition should, therefore, not be lightly discarded.

Id. at 94 n.6 (quoting FCC's opinion).

st Id. at 94-95.

so See id. at 96.

so Id. at $96-97$.

${ }^{57} I d$. at 97. 
must be "ground for reasonable expectation that competition may have some beneficial effect."

The Supreme Court has also held that the FCC has the power to choose one of several competing systems as the technical standard for an innovative broadcasting technology. In $R C A v$. United States, ${ }^{50}$ the Supreme Court ruled that "the Commission has power . . . to promulgate standards for transmission of color television that result in rejecting all but one of the several proposed systems." upheld the FCG's selection of the CBS color TV system as the standard, even though the system was incompatible with existing blackand-white receivers. ${ }^{61}$

The Court in $R C A$ also noted that "all apparently agreed" that

[t]he quality of the present [black-and-white TV] service, the improvements and reductions in price to the public that have been made, the incredible expansion of the industry as a whole, are all due to the fact that manufacturers could build upon a single set of long-range high-quality standards. ${ }^{62}$

This emphatic language suggests that the Court views technical regulation, including the choice of a single standard for broadcasting innovations, as conducive to the public interest. A presumption in favor of technical regulation is also implicit in the Court's view that the Act was designed to remedy the technical problems of interference between different radio broadcasters ${ }^{68}$ and to enable the FCG "to maintain . . . a grip on the dynamic aspects of radio transmission."

\section{The FCC's Mandate as Interpreted by Administrative Practice}

The traditional practice of the FGC is an important indicator of how the Commission has interpreted its mandate to regulate in the "public convenience, interest, or necessity." Before its decision on AM stereo, the FCG had always responded to innovative broadcasting technologies by promulgating a single set of technical standards thereby ensuring that transmitters and receivers utilizing the new technology would be compatible with each other (although not necessarily compat-

$88 I d$.

s9 341 U.S. 412 (1951) (dealing with the FCG's promulgation of technical standards for the then innovative technology of color TV broadcasting).

10 Id. at 416.

61 See id. at 417-20.

62 Id. at 418 (emphasis added). The majority opinion quoted this language from RCA's complaint. Id. at $418 \mathrm{n} .8$.

es See FCC v. Sanders Bros. Radio Station, 309 U.S. 470,474 (1940).

*4 FCC v. Pottsville Broadcasting Co., 309 U.S. 134, 138 (1940). 
ible with other means of broadcasting). ${ }^{65}$

In his dissent to the AM stereo Final Rule, Gommissioner Washburn pointed out that "[s]election of a single standard has been our practice for over 50 years. For example: monochrome and color TV, FM stereo, telephone and other communications systems were all designed to a standard selected by the FCG."

The FCG's traditional approach is illustrated by its deliberations regarding the introduction of color television. In 1947 several competing firms, including GBS and RCA, were developing color television systems. Each of these systems was incompatible with the others, ${ }^{67}$ just as the AM stereo systems developed by competing firms thirty years later were incompatible with other AM stereo systems. ${ }^{68}$ Then, the FCG considered whether to allow competing firms to place their color TV systems in the marketplace, where the public could choose the system it preferred. The FGG stated,

The answer lies in the nature of television and the fact that there are not enough frequencies available . . . for more than one color television system. In television ... the receiver and transmitter are related to each other as a lock and key. Unless they are both designed to meet certain fundamental standards, the receiver will be unable to accept the

os In its proceedings regarding subscription television service, the FCC stated,

In other broadcasting service we have taken steps to assure that receiving equipment used by the public be capable of utilizing signals from any station. To this end, we have required all broadcast stations in any band to use a single system of transmission so that receivers need not be altered or complicated to receive different stations. This requirement for a single system has been applied to basic broadcasting service, color TV, and FM stereo.

In re Amendment of Part 73 of the Comm'n's Rules and Regulations (Radio Broadcast Services) to Provide for Subscription Television Service: Further Notice of Proposed Rulemaking and Notice of Inquiry, 3 F.C.C. 2d 1, 13 (1966).

For examples of technical regulations creating a single standard that ensures compatibility of receivers and transmitters, see 5 Fed. Reg. 2382 (1940) (technical rules for FM subsequently amended and codified at 47 G.F.R. $\S 73.201-346$ (1983)); 6 Fed. Reg. 2282 (1941) (technical rules for television subsequently amended and codified at 47 C.F.R. $§ \S 73.681-88$ (1983)); 28 Fed. Reg. 13,623 (1963) (technical rules for FM stereo codified at 47 C.F.R. $73.322(1983)$ ).

In 1950 the FCC issued technical regulations selecting the CBS system as the standard for color TV, thus ensuring that color receivers and transmitters would be compatible with each other. The GBS color TV system, however, was not compatible with the older technology of black-and-white television. See infra note 71 and accompanying text.

${ }_{68}$ Final Rule, supra note 7, at 13,167 (Washburn, Comm'r, dissenting).

67 In re Petition of CBS for Changes in Rules and Standards of Good Eng'g Practice Concerning Television Broadcast Stations, 43 F.C.C. Rep. 79, 79-80 (1940).

${ }^{68}$ See supra notes 13-14 and accompanying text. 
transmissions from the transmitter. . . .

Thus, it is obvious that before permitting a new television service to become established on a regular basis, a decision must first be made on fundamental standards. Otherwise manufacturers of receivers could not start to build receivers, and the public could not purchase receivers with any confidence that they would be able to receive programs from all television stations, or that their receivers would not become useless immediately after they were purchased if the existing stations should change any of the fundamental standards. Under these conditions, it is entirely unlikely that television receivers would be bought on any mass basis. ${ }^{69}$

For these reasons, the FCC rejected a marketplace approach that would have permitted incompatible color TV systems to compete in the market. Instead, in 1950 the FCG chose the CBS system as the standard. ${ }^{\text {70 }}$

${ }^{60}$ In re Petition of CBS for Changes in Rules and Standards of Good Eng'g Practice Concerning Television Broadcast Stations, 43 F.C.C. Rep. 79, 80-81 (1980). In 1966 the FCG addressed the question of whether subscription television should be limited to a single technical system. The FCG stated,

There would appear to be advantages to using a single technical system for subscription television. If different systems are used, different decoding apparatus must be provided for the viewers to receive the several kinds of transmission. This might be inconvenient and expensive for viewers within the service areas of more than one subscription station who desire to receive several subscription stations, or for viewers who purchase decoders and later move to other localities in which different systems are used. . . . It is also possible that permitting different subscription systems might tend to restrict competition, rather than stimulate it, because viewers who install decoders for one system would be unable, without additional expense and inconvenience, to receive the subscription offering of another system using a different system.

In re Amendment of Part 73 of the Comm'n's Rules and Regulations (Radio Broadcast Services) to Provide for Subscription Television Service: Further Notice of Proposed Rulemaking and Notice of Inquiry, 3 F.C.C. 2d 1, 13 (1966).

70 See In re Amendment of the Comm'n's Rules, Regulations and Eng'g Standards Concerning the Television Broadcast Service, 41 F.C.C. Rep. 111 (1950). The choice of the CBS system was controversial because the GBS color system was incompatible with existing black-and-white receivers. Nonetheless, the Supreme Court upheld the FCG's selection of the CBS color TV system. See supra notes 59-61 and accompanying text. In 1953 the FCC changed the standard for color TV, choosing a color system developed by the National Television Service Committee that was compatible with existing black-and-white sets. See In re Amendment of the Comm'n's Rules Governing Color Television Transmissions, 41 F.C.C. Rep. 658 (1953). 


\section{The FGG's AM Stereo Ruling Violated Its Mandate}

This Comment argues that the FGC's decision to permit incompatible AM stereo systems to compete in the marketplace violated its mandate to regulate in the public convenience, interest, or necessity. When it issued its Final Rule in 1982, the FCG should have realized that the marketplace approach would (1) significantly delay widespread adoption of AM stereo; (2) increase the cost of AM stereos and cause other inconveniences to consumers; and (3) create a situation in which a manufacturer's market power and promotional expenses, rather than the technical qualities of the various systems, would dictate the market choice.

\section{A. Delay in Adoption of AM Stereo}

The market approach delays implementation of AM stereo because receiver manufacturers, broadcasters, and consumers are reluctant to invest initially in any one system that may soon be obsolete if a different system prevails as the market standard. ${ }^{71}$ The cost to an individual radio station of acquiring $\mathrm{AM}$ stereo transmitting equipment is between $\$ 10,000$ and $\$ 20,000,{ }^{72}$ and receiver manufacturers incur large start-up expenses when retooling to produce a particular system. The financial incentives to wait until a clear market leader emerges are thus large. Prior to adoption of the Final Rule, most broadcasters and receiver manufacturers urged FCC selection of a single system in order to avoid such delays. ${ }^{73}$

With the Final Rule, however, the majority of Commissioners ignored the possibility that the market approach would slow adoption of

71 See, e.g., AM Stereo Goes on the Air, Broadcasting, Aug. 2, 1982, at 23 ("Manufacturers will be reluctant to build any set until a standard has been fixed."); Final Rule, supra note 7, at 13,153 (Members of the FCG staff who "urg[ed] the selection of a single system believed that the 'marketplace' approach might result in a delay in the implementation of AM stereo because broadcasters and receiver manufacturers would be reluctant to make a substantial investment in a technology that might not ultimately be successful.").

One group owner of radio stations who delayed producing AM stereo for a while was Capital Cities Communication, which "earlier had decided to play it cautiously and not retool its AM facilities for stereo until an industry standard was set." Delco Makes Big News With Automobile AM Stereo, Broadcasting, Oct. 10, 1983, at 74 [hereinafter cited as Delco Makes News]. Capital Cities Communication has apparently reconsidered this decision to delay, however, and has begun testing the systems at a few of its stations. $I d$.

${ }_{72}$ AM Going Stereo, supra note 6, at 6F, col. 1.

73 FCC Gives Up on AM Stereo Choice, Will Leave it to Marketplace, BroADCASTing, Mar. 8, 1982, at 36; see also Final Rule, supra note 7, at 13,154 ("With ... few . . . exceptions, . . . those responding to the Further Notice preferred that the Commission select a single AM stereo system.") 
AM stereo. Instead, they focused on the problem of administrative delay. The majority opinion cited two comments received by the FGG. In one, $A B C$ asserted that "the marketplace [approach] is clearly preferable to continued, interminable delays"; ${ }^{74}$ in the other, NBC argued that the legal challenges resulting from the choice of a single system as the standard could delay AM stereo for many years. ${ }^{75}$

The majority's reliance on these comments is unpersuasive. The FCC spent five years gathering and evaluating data, ${ }^{76}$ presumably to determine which system was the most desirable. It could have eliminated continued administrative delay by choosing a system on the basis of the available information. ${ }^{77}$ Furthermore, the potential delays from lawsuits protesting selection of a single standard are unlikely to have exceeded the delays resulting from the market standoff that the Final Rule has produced. ${ }^{78}$

Indeed, experience since the Final Rule became effective on April $26,1982,79$ indicates that general adoption of AM stereo has been significantly delayed by the marketplace approach. By October 1983, less than $200^{80}$ of the 4,650 AM stations in the country ${ }^{81}$ were broadcasting in stereo. By March 1984, almost two years after the Final Rule was announced, only 315 stations $^{82}$ (approximately $6.8 \%$ of all AM stations

74 Final Rule, supra note 7, at 13,154.

25 Id.

76 The Final Rule was issued in March 1982, almost five years after the Commission began its AM stereo proceedings. The FCC was sharply criticized for taking so long. See, e.g., id. at 13,154; see also id. at 13,166 (Quello \& Fogarty, Comm'rs, concurring).

${ }_{77}$ When the FCC issued its Further Notice in 1980 requesting more technical data and comments, it stated, "We are confident that if we received no further information at all, and where [sic] thereby forced to use only the information [at] hand, we are in a position to choose an AM stereo system which would serve AM broadcasters and the American public very well." Further Notice, supra note 24 , at 59,356.

78 The delays likely to result from litigation challenging selection of a single system are difficult to predict. Upon appeal of an FCC order, a court may grant temporary relief, either requiring compliance with the challenged order or ordering restoration of the situation prior to the challenged order. 47 U.S.C. $\$ 402$ (c) (1976). Thus, a challenge to the FCC's selection of an AM stereo system as a standard could possibly result in no delay in enforcing this standard. In any event, the appeal might not take very long. When RCA challenged the selection of the CBS color TV system, only eight months elapsed between the FCC order implementing the selection (Oct. 1, 1950) and the Supreme Court's decision affirming the FCC's selection (May 28, 1951). See RCA v. United States, 341 U.S. 412, 412 (1951); see also id. at 421 (Frankfurter, J., dubitante).

79 See Final Rule, supra note 7, at 13,152.

80 By October, 1983, Harris had 65 stations using its system on the air, Kahn/ Hazeltine had over 50, Motorola over 35, and Magnavox had "just a handful." Delco Makes News, supra note 72.

o1 See Jockeying for Position at the Starting Gate, Broadcasting, Mar. 15, 1982, at 52 [hereinafter cited as Jockeying for Position].

82 Relying on figures supplied by the proponents of the four systems, an industry 
in the country) had acquired AM stereo broadcasting equipment.

AM stereo is a desirable technological improvement. That the public prefers stereo to monaural radio is demonstrated by the migration of the listening public from AM to FM and by the declining ability of AM stations offering musical programming to compete with similarly formatted FM rivals. ${ }^{83}$ AM broadcasters hoped that the implementation of AM stereo would grant them parity with their FM rivals; ;4 indeed, many have placed AM stereo "[h]igh on the list of possible saviors." implementation of this technology, it is contrary to the public interest.

\section{B. Increased Expense to Consumers}

The FCG's approach, which permits incompatible systems to compete in the market, has raised the cost of AM stereo for consumers. If several stations in the same geographic area are broadcasting with different AM stereo systems, the consumer who desires to hear all of them is confronted by expensive alternatives: she may either buy different receivers to listen to each of the incompatible transmitters, ${ }^{\mathbf{8 6}}$ or purchase a multi-receiver capable of decoding all four competing systems. ${ }^{87}$ Since adding AM stereo capacity to radios increases their cost

observer in March 1984 estimated that

Motorola has lined up almost 120 stations, with 94 of them on the air.

Kahn has shipped 93 exciters, the bulk of which are on the air . . . Harris has sold 98 exciters and put the majority "on the air." With just four stations on the air, Magnavox is running a distant fourth.

The AM Stereo Marketplace Struggles for a Standard, Broadcasting, Mar. 19, 1984 at 84 [hereinafter cited as Marketplace Struggles for a Standard].

${ }_{83}$ The revenues of FM stations are rising much faster than those of AM stations. Since 1979, "more listener-hours were spent tuned in to FM than AM radio in the United States." AM Going Stereo, supra note 6, at 6F, col. 3. FM's competitive edge is even greater in the critical and most profitable 18-to-35-year-old market. Id.

Recent ratings data on the ten most listened-to stations in each of the 25 largest markets (250 stations in all) clearly illustrate AM's decline in popularity. In none of the top 25 markets are a majority of the top ten stations on the AM band. Of these top 250 stations, only 73-fewer than a third-are AM. Only 41 of these AM stations play any kind of music programming, and of those, only 17 play pop or rock music. Ratings Leader: Adult Contemporary, Broadcasting, Aug. 29, 1983, at 64-66 (ratings data are from the Arbitron Spring survey of "metro" areas, with stations ranked according to the number of persons, age 12 or older, who listen to a station during an average quarter-hour period between 6 A.M. and midnight, Monday to Sunday) (stations that simulcast on AM and FM frequencies are tallied as FM stations in the author's totals).

8. AM Going Stereo, supra note 6.

s5 Future of AM: Think Positive, Broadcasting, Oct. 10, 1983, at 103.

86 See Final Rule, supra note 7, at 13,166 (Washburn, Comm'r, dissenting); see also the FCC's rationale offered during the subscription TV proceedings discussed supra note 70.

87 Sony and Sansui are producing multi-system receivers capable of decoding AM 
by thirty to fifty dollars, ${ }^{88}$ buying one receiver for each type of system transmitting in the area becomes extremely expensive. And "multi-system" or "universal" receivers capable of decoding all the systems also bear high price tags. ${ }^{89}$

In the Final Rule, the majority cited comments received by the FCC asserting that a multi-system receiver would be more expensive than a single-system receiver:

Matsushita stated that the additional cost for adding one system to present receivers would range from $\$ 10$ to $\$ 20$ depending on the system. They thought a doubling of that would be necessary for a multi-system receiver . . . .

Sony . . . stated that it believes that a multi-system arrangement would greatly increase the receiver production costs without providing the listener with any corresponding benefit.

The Consumer Electronics Group of the Electronic Industries Association [stated that] the added manufacturing costs [of a universal decoder] would raise the price to the consumer to possibly prohibitive levels. ${ }^{90}$

The majority blithely dismissed these concerns, declaring that "technological developments may lead to the possibility of inexpensive multisystem receivers."

The majority's optimism appears to have been unfounded. One year after the announcement of the Final Rule, Sony introduced a portable AM stereo/FM stereo radio capable of receiving all four AM stereo systems on one chip. As predicted, the portable multi-system receiver is expensive: its retail price is $\$ 88.95 .^{82}$

Confronted by such expensive alternatives, the consumer might re-

stereo transmissions by all four systems. Marketplace Struggles for a Standard, supra note 82 , at 84 .

88 AM Going Stereo, supra note 6. In January 1983 National Semiconductor claimed that the price of portable AM stereo receivers to be built by Magnavox would be "well under $\$ 20$." AM Stereo on Parade at CES, BROADCASTING, Jan. 17, 1983, at 116. However, since Magnavox AM stereo transmitters were being used by only four stations in March 1982, see supra note 82, a Magnavox portable receiver would probably do a listener little good.

80 See infra note 92 and accompanying text.

so Final Rule, supra note 7 , at 13,155 .

01 Id. at 13,157 .

82 See AM Stereo Flotsam, Broadcasting, Aug. 1, 1983, at 56; see also Delco Makes News, supra note 72; Marketplace Struggles for a Standard, supra note 82, at 84. Sansui is marketing a multi-system receiver with automatic signal switching and a stereo indicator light that retails for about $\$ 349$. Id., at 84,86 . 
spond by buying a single-system receiver, even though she must forego the ability to receive signals from incompatible AM stereo transmitters in the area. This consumer will receive less value ${ }^{93}$ for her purchase than she would have if the FCG had ensured compatibility by selecting a single standard. In short, by adopting a market approach the FCC has raised the price of AM stereo service for the consumer, thus violating its mandate to ensure that "radio communication service" is provided "at reasonable charges."

The market approach causes other inconveniences to consumers. A listener may find it difficult to ascertain the type of system being used by a station. ${ }^{85}$ Also, even if the listener purchases a receiver compatible with a station in her locale, she may encounter incompatible transmitters if she travels or moves to another area ${ }^{96}$ These additional inconveniences further demonstrate that the FCC has failed to meet the "public convenience, interest, or necessity" standard articulated by the Supreme Court. ${ }^{97}$

\section{Market Choice Determined by Market Power}

By abdicating its prescribed responsibilities, the FCG has also allowed the choice of a standard to be greatly influenced by the market power of receiver manufacturers. The concurring and dissenting opinions to the Final Rule pointed out that the market choice would not reflect technical superiority or consumer preference as much as marketing efforts and promotional expenses. ${ }^{98}$ This method of selection is contrary to the public interest.

Shortly after the Final Rule was issued, industry observers considered it likely that the Japanese, who dominate the receiver manufactur-

9s This assumes that the value of a stereo receiver to a consumer increases with the number of stations that the receiver can pick up in stereo.

os See supra note 46 and accompanying text.

9s In response to its Further Notice, the FGC received comments that argued that under a marketplace approach, "listeners would not necessarily know which systems would be used by each station in a particular area." Final Rule, supra note 7, at 13,155 .

${ }^{98}$ Id. at 13,167 (Washburn, Comm'r, dissenting); see also the FCC's rationale offered during the subscription TV proceedings and discussed supra note 70 .

${ }^{27}$ See FCC v. Pottsville Broadcasting Co., 309 U.S. 134, 139 n.2 (1940) (citing with apparent approval a Federal Radio Commission report that states that " $[t]$ he emphasis must be first and foremost on the interest, the convenience, and the necessity of the listening public, and not on the interest, convenience or necessity of the individual broadcaster or advertiser"); see also NBG v. United States, 319 U.S. 190, 216 (1943) ("The public interest to be served under the Communications Act is thus the interest of the listening public in the larger and more effective use of radio.").

${ }^{98}$ See Final Rule, supra note 7, at 13,166 (Quello \& Fogarty, Comm'rs, concurring); see also id. at 13,166-67 (Washburn, Comm'r, dissenting). 
ing market, would determine the standard. ${ }^{9 \theta}$ Broadcast magazine wrote, "The Japanese . . . could go home, sit down, and simply decide which system they would all make with total immunity from U.S. antitrust laws."100 Thus far, however, Japanese manufacturers have not exerted such influence. Rather, the largest domestic manufacturer of radio sets, Delco Electronics, may be be setting an industry lead that all will follow.

Delco, a subsidiary of General Motors, ${ }^{101}$ manufactures car radios for its parent company. After extensive testing, Delco endorsed Motorola as the best AM stereo system, ${ }^{102}$ and since early 1984 Delco radios utilizing the Motorola system have been available as factory options on Buick automobiles. ${ }^{103}$ By March 1984, Sherwood Electronics also decided to produce car radios employing the Motorola system, partly because "momentum for Motorola seems to be mounting." claims by Motorola spokesmen that other major domestic and Japanese manufacturers will follow Delco's lead by producing Motorola-only receivers, In March 1984Broadcast magazine concluded that the Motorola system had a competitive advantage and was the most likely of the four systems to become the industry standard. ${ }^{105}$ Whether or not Delco determines the standard, the market approach creates a strong temptation for receiver manufacturers and broadcasters to avoid the standoff described earlier ${ }^{108}$ by blindly accepting the choices made by the largest actors in the industry. ${ }^{107}$

By allowing the market choice to be determined by the largest companies in the telecommunications field, the FCG seems to have ignored the legislative history of the Federal Communications Act. According to the Supreme Court, Congress passed the Act " 'under the spur of a widespread fear that in the absence of governmental control the public interest might be subordinated to monopolistic domination in the broadcasting field." "108 Furthermore, the FCG is better suited to

35.

o9 See AM Stereo: The Solution Still Eludes, Broadcasting, Apr. 12, 1982, at

$100 \mathrm{Id}$.

101 See Delco Makes News, supra note 72.

102 See id.; see also Marketplace Struggles for a Standard, supra note 82, at 84.

${ }^{103}$ Marketplace Struggles for a Standard, supra note 82, at 84-85.

104 Id.

10 See id. at 84.

${ }_{108}$ See AM Stereo: The Solution Still Eludes, supra note 99, at 35.

107 Shortly after the FCC issued the Final Rule, it appeared that either the broadcasters or the receiver manufacturers would determine the market choice. AM Stereo: The Solution Still Eludes, supra note 99, at 35. By 1984 it appeared that receiver manufacturers were more capable of determining the market standard. See Marketplace Struggles for a Standard, supra note 82, at 84-85.

${ }_{108}$ NBC v. United States, 319 U.S. 190, 219 (1943) (quoting FCG v. Pottsville 
choose a system that serves the public interest than is a large manufacturer that is primarily concerned with its own financial interests.

\section{The Inadequacy of the FGC's Decision-Making Process}

The decision-making process employed by the FGC in reaching its Final Rule also appears inadequate when examined in light of the FCC v. RCA Communications, Inc. ${ }^{109}$ decision. As noted earlier, ${ }^{110}$ the Court in RCA Communications held that for the FCC "merely to assume that competition is bound to be of advantage" or to recite the benefits of competition "in an abstract, sterile way" is not sufficient. ${ }^{111}$ Before the FCG can adopt market competition as the standard in a particular instance, the Court held, the FCC must "conscientiously" evaluate whether competition will favor the public interest and must find "ground for reasonable expectation that competition [will] have some beneficial effect." 112

A simple assumption that competition is inevitably advantageous underlies the majority's reasoning in the Final Rule. The majority stated,

A very strong case would have to be made in order to override the inherent benefits of consumers making their own choices rather than having their decisions made by government. ... . [O]ur society generally has not seen fit to supplant the free decisions of consumers with those imposed by government, and there is no convincing reason why AM stereo presents a special case. ${ }^{113}$

Requiring a "very strong case" to justify departure from competition is tantamount to an assumption that competition is beneficial. The majority's references to society's general preference for competition and

Broadcasting Co., 309 U.S. 134, 137 (1940)). This statement by the Court is premised on the view that the legislative history of the Federal Communications Act of 1934 includes the legislative history of the Federal Radio Act of 1927. See FCG v. Pottsville Broadcasting Co., 309 U.S. 134, 137 (1940).

The majority opinion in the FCC's Final Ruling on AM stereo obliquely addressed the issue of whether the absence of governmental control would permit monopolistic domination of the market. It did so by arguing that governmental control would itself create a monopoly because selection by the FCC of a single system would grant the manufacturer of that system a monopolistic advantage. The majority conceded that the manufacturer would be required to "share part of his monopoly gains through licensing his patented invention to others." Final Rule, supra note 7, at 13,157-58.

${ }^{100} 346$ U.S. 86 (1953).

110 See supra text accompanying note 52.

"11 See supra text accompanying notes 47-58.

112 RCA Communications, 346 U.S. at 94-97.

11 Final Rule, supra note 7 , at 13,158 . 
to "our basically free enterprise society" as a justification for the marketplace approach to AM stereo ${ }^{114}$ is the sort of decision-making that the Court held impermissible in RCA Communications. ${ }^{115}$ The majority in the Final Rule listed, with little elaboration, four benefits that would result from the marketplace approach: (1) encouragement of technological improvements, (2) reduction in the costs of production, (3) reduction in price, and (4) allowance of consumers' freedom to weigh design factors. ${ }^{118}$ When the FCC in RCA Communications listed the first three of these as advantages that generally flow from competition, the Court held that such an "abstract, sterile" recitation of the benefits of competition could not justify the FGC's decision. ${ }^{117}$

Moreover, the majority's discussion in the Final Rule of the disadvantages of the market approach is so facile that it suggests an unwillingness to consider seriously the possibility that competition may not be beneficial. The majority proposed three downside possibilities: (1) no

114 Id.

116346 U.S. at $88-89,91-95$.

${ }^{116}$ Final Rule, supra note 7, at 13,157-58. One of the advantages of the market approach-price reductions resulting from competition in price-is not expressly mentioned in the majority's opinion. It is implied, however, by the majority's discussion of how selection of a standard by the FGC would curtail price competition and enable the manufacturer whose system was chosen to charge monopoly prices. Id.

${ }^{117}$ See supra note 53 and accompanying text. The Court in RCA Communications was bothered by the FGG's reliance on abstract benefits of competition without careful analysis of whether these benefits would actually be realized in the particular context under consideration. See RCA Communications, 349 U.S. at 94-97. Indeed, in $R C A$ Communications the FCC found that competing radiotelegraphic circuits would not lead to a reduction in prices charged to consumers, see id. at 88 , yet one of the general benefits of competition on which the FCC relied as justification for its action was that competition tends to reduce price. See id. at 94 n.6.

In many respects, the majority's analysis in the Final Rule of the benefits of competition is also generalized and divorced from the particular context of AM stereo. For example, the majority discussed one supposed advantage of the marketplace approach-that consumers could weigh design characteristics themselves-in an abstract way. The majority stated, "The Commission thinks that decisions being made by those affected is, in principle, a preferred course to government imposed decisions. Thus the Commission believes that a better decision will result from our relying on market forces." Final Rule, supra note 7, at 13,157 (emphasis added). The majority did not analyze whether, in the specific context of AM stereo, consumers would have enough information to be able meaningfully to weigh design characteristics and whether consumer preference for a particular system would influence the market choice if the standard is ultimately determined by broadcasters or receiver manufacturers following the lead of a large company.

Likewise, the majority in the Final Rule implies that the marketplace approach is generally advantageous because competition in pricing will lead to a reduction in prices. Id. at 13,157-58. The majority ignores the fact that, within the specific context of AM stereo systems, the listener who desires to hear several stations using incompatible transmitters faces two expensive alternatives: he can either buy more than one singlesystem receiver, or he can buy a costly multi-receiver. See supra notes 87-93 and accompanying text. 
system would be chosen due to lack of consumer interest in AM stereo; or (2) even if there were substantial consumer interest in AM stereo, that interest would be spread so thinly among various individual manufacturers that no single system would be adopted widely enough to sustain AM stereo in the market; or (3) no system would be chosen because consumers and manufacturers would be reluctant to invest in a new system that could soon be obsolete. ${ }^{118}$

The majority discounted the first possible disadvantage by arguing that if consumer interest were so low, AM stereo would not be adopted on a mass scale regardless of whether the FCC adopted a market approach or selected the standard itself. ${ }^{119}$ Likewise, the majority dismissed the second possibility by arguing that if the market were too thin, the competitive process of some firms failing and others increasing their share would result in the surviving firms having enough business to sustain continued participation in the AM stereo market. ${ }^{\mathbf{1 2 0}}$

These two "disadvantages" were put forth only to enable easy refutation. The possibility that AM stereo will not be popular with consumers is extremely unlikely. ${ }^{121}$ The FCG cannot justify its refusal to select a technical standard by referring to a remote chance that this regulation will be unnecessary. This approach is not the "conscientious" analysis that the Court required in RCA Communications.

The third downside possibility raised by the majority was a genuine problem, but the majority summarily dismissed it by arguing that reluctance to invest because of possible obsolescence was typical of "the competitive process which virtually every new industry or product must endure."122 The FCG majority did not consider the special nature of the AM stereo market, in which failure to set standards to ensure compatibility of transmitters and receivers sharply aggravates the problem of potential obsolescence. This omission by the majority is particularly noteworthy when compared with the FCC's analysis in earlier proceedings regarding color television, proceedings in which the FCC stated that "unlike the automobile or vacuum cleaner which remains capable of operation after a new model is brought out, a change of any one of the fundamental standards at the transmitter would immediately make all receivers built for the old standards obsolete."123

The FGG majority did not discuss other, much more probable ad-

118 See Final Rule, supra note 7, at 13,158.

119 See id.

120 See id.

121 See supra notes 83-85 and accompanying text.

122 See Final Rule, supra note 7, at 13,158.

123 In re Petition of CBS for Changes in Rules and Standards of Good Eng'g Practice Concerning Television Broadcast Stations, 43 F.C.G. Rep. 79, 81 (1940). 
verse consequences of the market approach such as delay, increased cost, and the risk that the choice of a system would be determined by market power. ${ }^{124}$ In short, the majority's analysis of the pros and cons of the marketplace reflects more a general assumption that deregulation and competition are beneficial than a careful analysis of whether allowing incompatible systems to compete in the context of AM stereo would serve the public interest. This is exactly the approach-endorsement of free competition without consideration of its practical consequences-that the Supreme Court objected to in $R C A$ Communications.

\section{CONCLUSION}

Commissioner Quello has rightly characterized the AM stereo Final Rule as the worst decision made by the FCG in $1982 .{ }^{125}$ By permitting incompatible AM stereo systems to compete in the market and by regulating without regard for the practical consequences of its actions, the FCC violated its responsibility to regulate in the public convenience, interest, or necessity.

Although deregulation in many instances is beneficial, the FCC must remember that it received its mandate from a Congress that believed that affirmative regulation of telecommunications by a government agency, rather than total deference to market forces, was necessary in many circumstances to further the public interest. The experience with AM stereo indicates that a determination of technical standards by the FCC is required.

124 See supra notes 72-109 and accompanying text.

125 See FCC in 1983: Undaunted Deregulatory March, Broadcasting, Jan. 17, 1983 , at 80 . 